\title{
Teeters, (Taught)ers, and Dangling Suspended Moments: Phenomenologically Orienting to the Moment(um) of Pedagogy
}

\author{
Kelsey Knowles, University of Ottawa \\ Email:kknow019@uottawa.ca \\ Dr. Rebecca Lloyd, Associate Professor, University of Ottawa \\ Email: Rebecca.Lloyd@uottawa.ca
}

\begin{abstract}
My intention in writing this article is to illustrate how I engage with the process of orienting to the meaning of pedagogy by inquiring into several moments in my life where I am able to fully experience its (moment)um. I begin this phenomenological inquiry by plunging into my experience on a teeter-totter as a young child, and use the sense of ups and downs as a metaphor for the tensions of weight and weightlessness, comfort and challenge that characterize the pedagogical world. I then attempt to gain a more perceptual understanding of pedagogy by narrowing in on the suspended moment, which becomes a metaphor for the pedagogical moments of support, vulnerability, and opening that emanate from this tension. In these particular moments, I am able to dwell in the spaces in-between my everyday ups and downs and become existentially conscious and pedagogically connected to the world around me. By metaphorically connecting each of these moments to my teetertotter experience, I illustrate how embracing the tensions of life and allowing myself to dwell in a suspended moment, deepens my perceptual understanding of pedagogy and influences my current pedagogical practice as a new teacher and master's student.
\end{abstract}

\section{A Methodological Prologue}

Orienting to a phenomenon within the context of van Manen's first methodological step, turning to a phenomenon which seriously interests us, "implies a particular interest, station or vantage point in life" (van Manen, 1990, p. 40). One approaches a phenomenon with a curiosity in that phenomenon; a curiosity that stems from one's own life circumstances, past experiences, and sense of wonder for the meaning of the phenomenon in question. To orient to a phenomenon means to explore what it is that calls us to an inquiry, and then to make explicit our biases and position within the world.

I am called to this inquiry by my sense of wonder for the pedagogical moment, a phenomenon which has become the focus of my master's thesis. The intention of writing this piece for the "Phenomenological Notes" section of Phenomenology \& Practice is to illustrate how I engage with the process of orienting to my phenomenon of interest as part of this larger master's research project. 
As I journey through van Manen's first methodological step, I inquire into several moments in my life where I am able to fully experience the (moment)um of pedagogy. I begin this inquiry by plunging into my experience on a teeter-totter as a young child, and use the sense of ups and downs as a metaphor for the tensions of weight and weightlessness, comfort and challenge that are experienced in my everyday life. The unpredictable nature of moving up and down, or feeling caught in a suspended dangle both perceptually and conceptually, orients me to the senses of invigoration, excitement, unpredictability, and insecurity that characterize the pedagogical world.

Amidst this shifting, there are also moments when the tensions created by these ups and downs cease my (moment)um. It is these suspended moments that "break through ordinariness" or "violate expected smooth functioning" (Stern, 2004, p. 34) that allow me to and become conscious of the world around me. It is within these moments that restrict my movement when my field of perception shifts from what lies in front of me to what may lie beyond what meets the eye. Each moment invites me to step outside of my fast paced life, which marches to the cadence of a ticking clock, into a realm where time seems to stand still, where I become existentially attuned to the living, pulsing world around me and am able to fully see, understand, and act for those in my trusted care (van Manen, 1991).

By situating each living experience around a relational position on the teeter-(taught)er (such as providing a child with support, maintaining firm footing, or moving closer to a child's side), I show how phenomenological research provides the space to achieve deeper meanings and perceptual understandings of phenomena through metaphorical and experiential orientations, as it is through these very orientations that I am able to see the inherent pedagogical meanings and possibilities ${ }^{i}$ that each individual moment has to offer.

\section{Phenomenologically Orienting to Pedagogy}

\section{Pedagogy}

I enter this inquiry with a conceptual understanding of pedagogy. I know that pedagogy stems from a space of morality, where a pedagogue's primary responsibility is to "serve the child" (van Manen, 1991, p. 6) by adhering to what Langeveld called pedagogy's fundamental values: security, reliability, and continuity (Langeveld, 1979). Pedagogy is not about rational decision-making, it is about making choices based on our inner senses of morality and deeply rooted care for those who we teach, parent, or mentor. To be pedagogical means to see beyond the semantics of educational theory and policy, and to look immediately and directly to the child (Langeveld, 1979).

I realize, however, that this conceptual understanding of pedagogy is limited, as it is only when we have responsibilities for children that we are able to gain a fuller, more perceptual and experiential understanding of what pedagogy means:

While we should be able to recognize the meaning and significance of pedagogy from our childhood and personal child-life experiences, it should also be pointed out that we may not fully be able to grasp what pedagogy means until we have lived ourselves with children or young people for whom we hold responsibilities (van 
Manen, 2012, p. 10-11).

This seminal quote by van Manen thus inspires this article and drives my search for a more perceptual understanding of pedagogy. As I weave through various personal child-life experiences, and share anecdotal narratives of my more recent response-abilities as a teacher and master's student, I am orienting to the "significance" of pedagogy and am beginning to "grasp what pedagogy means" (van Manen, 2012, p. 10-11).

I begin each section of this article with a textual journal entry that focuses on a different concept of pedagogy. I begin by exploring the meaning of in loco parentis, which, by definition, means to "act in the place of a parent" (van Manen, 1996, p. 6), through a childhood experience with my mother. In subsequent sections, I attempt to gain a more perceptual understanding of pedagogy by re-living moments of shifting support, dangling vulnerability, and attuned opening. My ultimate purpose is to share personal moments of living pedagogy. By orienting to pedagogy through these moments, and by metaphorically connecting each of these moments to my teeter-totter experience, I hope to illustrate how embracing the tensions of life, and allowing oneself to dwell in a suspended moment, can open up possibilities (Aoki, 1991; Bhabha, 1994; Palulis, 2014) for response-able, (intension)al, pedagogical practice.

\section{Phenomenology}

Van Manen (1990) inspires my phenomenological orientation and attitude in this search for meaning, as I am focused on accessing, unveiling, and understanding the meanings of my most basic, primordial experiences by studying 'the 'here and now' of a situation... [to] reflect an 'insider's' experience" (Pinar, Reynolds, Slattery, \& Taubman, 2008, p. 412). Through the orienting process, this attitude or lens affords me the "hermeneutic ability to make interpretive sense of the phenomena of the life world in order to see the pedagogic significance of situations and relations of living with children" (van Manen, 1990, p. 2). To see through this pedagogical and phenomenological lens means that I see children outside of the academic, behavioral, or social box that has been created by policy developers and education theorizers. This attitude forces me to see each child in the subsequent anecdotes "without reducing him or her to a diagnostic picture, a psychological type, a set of factors on a scale or a theoretical category" (van Manen, 1996, p. 12).

As I shift to this more phenomenological point of view, I am learning that meaning is "methodologically embedded in language" (van Manen, 1996, p. 10). Therefore, in an attempt to access the deeper pedagogical meanings of each suspended moment, I share each experience through textual journal entries to allow these moments to speak and show their own significance (Pinar et al., 2008). I do this as an "expressive means to penetrate and stir up the pre-reflective substrates of experience as [I] live them" (van Manen, 2014, p. 240). This "expressive means" provides the reader with the opportunity to transcend the language and textual descriptions into a space where they can identify with the universal qualities of each moment.

\section{Teeters, (Taught)ers, and Dangling Suspended Moments: Phenomenologically Orienting to the (Moment)um of Pedagogy}


We meet at the same time, each going for a different side of the homemade teetertotter that sits in the schoolyard.

I soar into the air while my counterpart's side of the totter hits the ground. In this momentary suspension, I am fixated on the person in front of me and brace myself as she makes an aggressive jumping motion. My stomach reaches my throat as I plummet towards the gravel surface. I quickly find the strength to support my fall. I feel exhilarated.

In three seconds, I am soaring into the air again. My knuckles turn white as I grip the handles, preparing for that same sense of exhilaration that comes from a quick drop

The drop never comes.

Tension overcomes my body as I stare down the wooden plank at the grade-five student. Removing her hands from the handles that have now become my lifeline, she interlaces her fingers behind her head as if she were relaxing in a chair. Laughter spills out of her mouth as she sees the vulnerability in my eyes. I try to engage her in a silent power negotiation as I sense the profound weight of blood rushing to my feet that are now dangling four feet from the ground. I begin to imagine what would happen to me if I were to fall or jump from this height.

For the first time, I look across the playground and notice the other students swinging on swing sets and playing tag. In this attuned moment of weakness, I know who has the power.

As I long to play tag with the other kids, a profound sense of opening allows me to see the deeper meaning in this powerlessness.

I will never do this to anyone.

\section{Shifting Support: A Suspended Moment Midst Security and Insecurity}

van Manen (1991) reminds us that we should not mistake pedagogy as existing only within the realm of the school and curriculum; rather, pedagogy embodies the very relations that are characteristic of a strong parent-child connection. Thus, as a way of first exploring the "deep connections between the nature of teaching and of parenting" (van Manen, 1991, p. 6) I begin my perceptual quest for meaning by reflecting on a childhood experience with my mother as a way of understanding pedagogy and its inherent in loco parentis relation: ${ }^{i i}$

I jolt awake. My Little Mermaid alarm clock ticks and tocks. It is 2:15am - my usual waking time. The wind whistles through the trees outside my bedroom. The 
house creaks. The windows shudder. I try to fall back asleep, but my mind remains fixated on the noises that are brought to life by this howling night. I begin to panic. My ticking clock is a constant reminder that I am still awake - still alone - still frightened. A faint dinging noise tells me that it is 3:00am. I decide to give in. I kick off my blankets and tip toe to my bedroom door. My father's inhales and exhales grow louder as I approach the end of the hallway. I take one step into my parents' bedroom, purposely stepping on the creaky part of the floor. I stop. The light of the moon allows me to see a soft silhouette of my mother, who is now sitting on the edge of her bed searching for her slippers. Without any exchange of words or questioning looks, she follows me back to my bedroom. As I nestle in beside her, the noises in the house begin to fade and all senses of anxiety diminish.

As I reawaken my senses in an attempt to dig to the deeper layers of my experience with my mother, I am propelled towards a space where our 2:15am routine has begun to shape my understanding of what pedagogy and in loco parentis truly means. I realize that she could have sought help to fix my insecurities from a doctor or psychologist, which would have been the textbook, authoritative thing to do. Instead, she knew that this routine only became our reality because of what happened in 1996, when my best friend's mother was killed in a car accident. She looked beyond the medical lens of what connotes anxiety, evaded the tensions of parenting rules against waking up in the middle of the night, and allowed herself to experience a softening - a letting go. It is through this softening, or this subtle tipping of the teeter-totter in my direction, that she was able to see my side more clearly: a child living in constant fear of losing her mother. As I reflect on these moments, the significance of what van Manen (1991) describes as in loco parentis shines through. Like my mother, who was not grounded by a set of rules but rather by compassion for the lived reality of her child in front of her, I attune to the concept of pedagogy in a similar way. I sense that pedagogy could shift, from my prior notion of being simply a buzz word in my teaching text books, to a concept with layered, overlapping, and coexisting perceptual meanings of love, compassion, and support.

\section{Dangling Vulnerability: A Suspended Moment Midst (in- tension)al and Un(in-tension)al Consequences}

What is it like to live without the love, compassion and support that I received from my mother? What is it like to dangle vulnerably, without the supporting intervention from a caring parent or mentor? What happens when that parent or mentor does not see a child's innermost needs? These questions, and the following quote from van Manen, inspire me to share Amy's experience:

It is important to realize, however, that there are ongoing events and experiences in children's lives that are not of our making intentionally. In fact, many of our own routine or otherwise "thoughtless" behaviors may influence children, for better or worse, in ways that we did not intend (van Manen, 1991, p. 18). 
We sit sipping coffee on a Saturday morning in November. I try to suppress the guilt I feel for not having reached out to Amy since I left for university last August. I am eager to hear about how she is doing in her first year of high school.

"How is the basketball team going" I ask.

"Umm" she pauses, "I don't think I am going to play this year".

My body language must be communicating my frustration for her decision not to play, as she immediately begins to tell me reasons why she isn't on the team. "The girls are really bitchy", she says. "They think they are better than everyone else".

I know the girls she is playing with, and know that they come from two-parent, well-to-do, well-known families. Having come from one of those families myself, I imagine that most of the girls and their parents are friends - with each other, and with the coach.

Amy is an anomaly - a girl from a troubled home trying to fit into a group where she feels she doesn't belong. I want to know more, but I don't want to push her too far and make our morning coffee feel like an interrogation - an experience she has become quite familiar with since her first police encounter two years ago. I ask what happened.

"Well, in basketball practice the other day, one of the girls just gave me this look. You know, the look you get when someone doesn't like you”.

I picture Amy running down the court in my old basketball shoes I gave her a year ago, right next to nine shiny pairs of the latest Air Jordans. I see that Amy wants to tell me more, but isn't sure if she should. I encourage her to open upto tell me what happened.

"So I...I went to the dressing room and stole one of their iPods. I kind of, you know, moved a few things around and took a couple of things. I was so mad". A look of sadness and rage fills Amy's eyes as she stares at me, seeking some sort of approval for her decision. "The coach doesn't want me anymore...Whatever, I don't care, and neither do they”.

Amy was my cousin, a young girl who struggled through each day, looking for someone to support her to safety. Although she was surrounded by a loving family, this support system wasn't enough to guide her back to a space where she felt comfort - a space that most of us are able to reconnect with after a traumatic experience because we have been taught how to cope and how to gain momentum in times of weakness and vulnerability. ${ }^{\text {iii }}$

Amy's peers knew that they would never get into trouble for just a simple look shot her way during a basketball game. For them, this look may have meant nothing but for Amy, a girl who had never been taught how to control her anger, it was a breaking point. In this moment, the gesture became a "language" (van Manen, 1990, p.183), telling Amy that her 
peers, her coach, and the rest of the school had more weight, more power, and more control. For Amy, the tensioned space created by the ups and downs of life were overpowering. The weight became so great, so one sided, that she was left alone for too long, forcing her to seek new ways to evade the ongoing pressures of daily life. Only five short years later, Amy overdosed on drugs, leaving behind a loving family and a pedagogical lesson for me to learn.

What if her situation would have been dealt with differently? What if, in a heightened level of attunement, the coach would have been able to fully make sense of the look of hurt in Amy's eyes? What if, for a moment, he was able to see beyond the "troubled kid" reputation, and see her for who she was - a young person who was vulnerable, powerless, and isolated from her peers? I wonder whether a different action or reaction to this simple gesture from her peers could have prevented what happened in the next five minutes, and the next five years.

As I continue to develop my own philosophy as a new teacher, I am reaching for an answer as to how such a young girl's vulnerabilities could have gone unnoticed for so long. In this tensioned state, I find myself oscillating between defensiveness and anger. The part of me that defends the coach thinks perhaps he chose to step back and give Amy the opportunity to handle this on her own. The part of me that is angry, however, realizes that there is "a difference between tactfully stepping back and stepping out altogether" (van Manen, 1991, p. 162).

\section{Attuned Opening: A Suspended Moment Midst Responsibility and "Response-ability"}

My personal experience with my mother, and my growing frustration with Amy's life, provide me with an inner pedagogical (moment)um. In the following story, I share one of my first experiences as a teacher, when this pedagogical momentum propelled me towards a space where I became attuned to my student's vulnerabilities and open to providing support.

I sit alone in a classroom with David after school. David was supposed to play soccer this afternoon, but instead, his homeroom teacher asked that he stay inside and finish his math problem that he didn't do in class because he was fooling around. "He's our troubled kid" the other teachers tell me. "It's just the way it is".

As the clock in the empty classroom ticks in unison with my pulsating heart, I ask David to read his math problem to me. He changes the subject and directs my attention to a cool pencil he got from his friend on the bus. I smile, acknowledge the uniqueness of the pencil, and redirect his attention to the math question.

David stares at the text in front of him. I see his eyes dart from one end of the page to the other. "David?" I ask. "I am reading in my head" he says. I give him a minute, but the looming presence of expectation prompts me to break the silence. "David?" 
David kicks his chair out from underneath him and gravitates toward the window that looks over the soccer field - his attention now fixated on the game he would much rather be playing. I clench my red pen and wait for David to come back to my side of the room. The ticking of the clock dissipates as my thoughts about David's past begin to compete with my ultimate goal for this lesson. I experience extreme tension between what I am expected to teach, and how I want to respond in this moment; a tension that is pulling me towards meeting this teacher-directed outcome, not towards what David truly needs.

I soften my grip on my red pen and make my way to the table where David is now sitting. And it is in this moment that I realize something.

\section{...David does not know how to read.}

Moments of full engagement with our world "carry a sense of consequence", requiring of us some sort of "mental or physical action" in response to our "breakthrough to consciousness" (Stern, 2004, p. 34). ${ }^{\text {iv }}$ In this suspended moment with David, a moment of full engagement amidst the hustle and bustle of a regular school day, I knew I had a responsibility to act. According to my curriculum documents and the looming presence of a fast approaching test, my responsibility resided with the student's mathematical preparation: continuing to be the authoritarian, punishing David for his misbehaviors, and demanding work when work needed to be done. Yet, as I reflect on this experience with a pedagogical attitude, I suppose in this moment I also became open to seeing my "responseability" (van Manen, 1990, p. 146) - my ability to value my felt sense over my rationality, to evade my preconceptions of what it meant to be a classroom manager, and to respond to David as a person, not as a test score. Within this tension I was "guided" by the "pedagogic good" (Aoki, 1991), which forced me to recognize that I had to leave my firmly rooted authoritarian position and dwell amidst "responsibility" and "response-ability". I had to connect with David in a way that allowed him to overcome his vulnerabilities in this suspended moment and arrive in a space where our relationship was built on trust and equality, rather than power and control.

These prolonged moments that enter awareness bring me back to that day on the playground: a day that left me feeling weightless and weak,; a day that constantly reminds me of the inequalities and injustices that exist within the hierarchical structure of the teaching world; and a day that reminds me that I have the response-ability to take action and to never leave my students in a vulnerable dangle. It is these suspended moments that violate the smooth functioning of my fast paced life and remind me to always empower others who find themselves in a state of powerlessness. I am learning that it is within the interval of this tensioned space, and within the attuned suspended moments that occupy this space, where I must learn to look around the playground and attune to the very things that are in front of me. I must see beyond the abstract language of curriculum documents, requirements, and test scores in order to pedagogically understand "what it is that children bring with them, what defines their present understandings, mood, emotional state, and 
readiness to deal with the subject matter and the world of the school" (van Manen, 1996, p.7).

\section{Shifting Support, Seeing Vulnerability, and Being Open to Moving to the Child's Side}

For most of my life, I have been taught that success is defined by my confidence, my authority, and my ability to find and maintain firm footing even in times of instability and uncertainty. Yet, as I orient to the meaning of pedagogy through my living experiences, I am beginning to challenge this authoritative philosophy that has characterized most of my professional and academic life. If I remain grounded in my confidence, power, and ideas, how will I be able to reach the young people I want to help? If I am never willing to uproot, to weaken my firm footing, to "go to the child's side" (van Manen, 1991, p. 155), and to shed my authoritative preconceptions, how will I be able to provide support to others in their moments of vulnerability? How can I move "away from binary thinking to an inbetween space" (Yoshimoto, 2011, p. 79) and work with, rather than against my students to maintain a precarious balance ${ }^{v}$ amongst life's unpredictability?

As I relive my mother's undying love, compassion, and willingness to shift support, I perceptually understand that pedagogy is about knowing "where the child is" and "how the child sees things" (van Manen, 1991, p. 155). As I write about Amy's vulnerable escape from her unsupported life, I am reminded that I must step beyond the tensions and labels that can often prevent me from truly seeing my students' needs, and (in-tension)ally act in their best interests. Through my experience with David, I know that it is my responseability to move (for)ward, for each of my students, like my mother did for me, into a space where I can truly see, and where we can deal with the instabilities of life together.

My bare feet dig into the gravel bed that lies beneath my wooden seat. I look up to see the sun creating a divine-like aura around the tiny child that sits opposite me. Although the glare of the sun prevents me from seeing her facial expression, the memory of my own childhood teeter-totter experience, my moment with David, and the lessons I learned from Amy cloud my thoughts and I am reminded of what this unsupported, suspended moment might feel like for the little girl. Without hesitation, I try to maintain my balance as I slowly pull myself closer to the child, one inch at a time. The closer I get, the more level the eight-foot cedar plank becomes and the tension created by both of our bodies allows the teeter(taught)er to move ever so slightly. As I draw closer and closer, the glare of the sun dissipates and a look of pure joy stares me directly in the eyes.

As I orient to each of these suspended moments that interrupt the ups and downs of my everyday life, I am able to engage in a "simple, yet profound gesture" of "closing, blurring, or shifting [my] eyes from [what lies] ahead" (Lloyd, 2011, p. 129) towards a space where a deeper seeing and perceptual understanding of pedagogy can flourish. ${ }^{\mathrm{vi}}$ This seeing, similar to the moment that emerged when I was held against my will on that teeter-totter many years ago, is now part of an intentional consciousness I carry forward in my future pedagogical research, reminding me to always support, not scrutinize; to inspire, not intimidate; and to overcome, never overpower. 


\section{A Methodological Epilogue}

By orienting to the various teeters, (taught)ers, and dangling moments that characterize my pedagogical experiences, I have simultaneously lived through the ups, downs, and moments of suspension that characterize the living experience of phenomenological inquiry. I have engaged in a variety of discussions and writing workshops and have written and re-written countless drafts, vignettes, and personal anecdotes about my experiences.

The methodological notes strategically placed as textboxes beside each vignette illustrate the metaphorical positioning of the significant moments that form the basis of this inquiry. What it is like to be vulnerable (calling to my mother in the middle of the night), to experience an imbalanced power struggle (Amy's experience on her basketball team), and to attune and respond to a child's needs (realizing that David cannot read) are thus essential themes that form the basis of my orientation towards the meaning of pedagogy. They are also apparent in my initial and final examples of moving on a teeter-(taught)er. Note that taught is emphasized for two reasons: the tension involved in moving towards a relational understanding of pedagogy, as well as the notion of being taught a life lesson through recollecting meaningful experiences.

By turning and orienting to a phenomenon with a sense of interest, curiosity, and wonder, as van Manen $(1990 ; 2014)$ suggests, I have taken my first step onto the unpredictable and emergent path of a developing phenomenologist. Methodologically, I have learned how perceptual understandings of phenomena deepen with each written draft, discussion, question, tension, and metaphorical reliving that happens throughout the orienting process. I know that to maintain this "strong and oriented relation" (van Manen, 1990 , p. 135) throughout the next phase of my research means to be able to know this "vantage point" and these biases, to be able to "hold them deliberately at bay" (van Manen, 1990 , p. 40) when I look to the experiences of others, and to re-integrate them at times when my personal investment in the research is warranted. As I begin to engage with the remaining steps of phenomenological research in my larger inquiry into the meaning of pedagogical moments for pre-service teachers, I plan to maintain this "oriented relation" (van Manen, 1990, p. 135) by returning to these suspended moments and by never losing the sense of the wonder, curiosity, and (moment)um that propelled me to this inquiry in the first place.

\footnotetext{
i I refer to "possibilities" here as a way of connecting with the research of Palulis (2014), Bhabha (1994), and Aoki (1991) who write about the inherent possibilities that exist within our "hybrid in-between spaces" (Palulis, 2014, p.120). Palulis (2014) writes that this interval that exists within the tensioned in-between spaces (of changing identity, role, authority, etc.) is an "interval in which possibilities might thrive" (p. 120). As Bhabha (1994) points out, these spaces are "the conditions through which newness comes into the world" (p. 227). I write about the pedagogical moments that exist within this tensioned interval as a way of intertwining my interest in existential (temporal, relational, corporeal, spatial) -consciousness (van Manen, 1990 ) with the profound works of tension created by those before me, as I believe that it is within our moments of full consciousness (that exist within these tensioned spaces) where newness and possibility can come into the world.

ii A methodological note: It is within this section of the article when I personally orient to what it is like to feel vulnerable, to exist on the weaker side of the teeter-totter, and to then physically, emotionally, and perceptually feel a shifting in support, or a tipping of the teeter-totter in my direction. I attempt to "show how meaning reveals itself" (van Manen, 2014, p. 48) through this relational metaphor of the teeter-totter.
} 


\footnotetext{
iii A second methodological note: Through Amy's story I attempt to bring "experience vividly into presence" through "experiential anecdote" (van Manen, 2014, p. 241) as a way of orienting to what it is like to see a child caught in a vulnerable dangle for too long.

${ }^{\text {iv }}$ A third methodological note: In this third relational position on the metaphoric teeter-totter, I now orient to what it is like to personally attune to a child's needs, to experience a pedagogical seeing, and to know my response-ability to help that child.

"I use the term "precarious balance" instead of only "balance" because I recognize that, in life, things will never be fully balanced and stagnant, nor should they be. The reality of living in an unstable world means that there are always going to be ups and downs, we are always going to be oscillating between forces pulling us in all directions. We need to be willing to move away from binary thinking, to move closer to students so we can live through these ups and downs with them (in an in-between space), not against them.

${ }^{\text {vi }}$ A fourth methodological note: In this fourth and final anecdote, I return to my childhood teeter-totter and draw from each of the pedagogical lessons I have learned in the previous stories as a way of orienting to a sense of becoming the pedagogue who physically moves to the child's side.
}

\section{References:}

Aoki, T. T. (1991). Teaching as in-dwelling between two curriculum worlds. In W. F. Pinar, \& R. L. Irwin (Eds.), Curriculum in a new key: The collected works of Ted. T. Aoki (pp. 159-166). Mahwah, New Jersey: Lawrence Erlbaum Associates.

Aoki, T. T. (1993). Legitimating lived curriculum: Towards a curricular landscape of multiplicity. Journal of Curriculum and Supervision, 8(3), 255-268.

Aoki, T. (2000/2005). Language, culture, and curriculum. In William F. Pinar (Ed.), Curriculum in a new key (pp. 321-329). Mahwah, New Jersey: Lawrence Erlbaum Associates, Publishers.

Bhabha, H. (1994). The location of culture. London, UK and New York: Routledge.

Langeveld, M. J. (1979). Beknopte theoretische pedagogiek [(Originally published in 1943.)]. Groningen: Wolters-Noordhoff.

Lloyd, R. J. (2011). Awakening movement consciousness in the physical landscapes of literacy: Leaving, reading and being moved by one's trace. Phenomenology \& Practice, $5(2), 70-92$.

Palulis, P. (2014). Paleographies of Aokian discourse: A geneology of border pedagogies and generative possibilities. In W. Hurren, \& E. Hasebe-Ludt (Eds.), Contemplating curriculum: Genealogies/times/places (pp. 156-167). New York, NY: Routeledge.

Pinar, W. F., Reynolds, W. M., Slattery, P., \& Taubman, P. M. (2008). Understanding curriculum. New York: Peter Lang Publishing Inc.

Pinar, W. F. (2005). "A lingering note": An introduction to the collected works of Ted. T. Aoki. In W. F. Pinar, \& R. L. Irwin (Eds.), Curriculum in a new key: The collected works of Ted T. Aoki (pp. 1-85). Mahwah, New Jersey: Lawrence Erlbaum Associates. 
Stern, D. N. (2004). The present moment in psychotherapy and everyday life. New York: W.W. Norton.

van Manen, M. (1990). Researching lived experience: Human science for an action sensitive pedagogy. London, Ontario: State University of New York Press.

van Manen, M. (1991). The tact of teaching: The meaning of pedagogical thoughtfulness. London, Ont.: Althouse Press.

van Manen, M. (1996). Phenomenological pedagogy and the question of meaning. In D. Vandenberg (Ed.), Phenomenology and educational discourse (pp. 39-64). Durban: Heinemann Higher and Further Education.

van Manen, M. (2012). The call of pedagogy as the call of contact. Phenomenology \& Practice, 6(2), 8-34.

van Manen, M. (2014). Phenomenology of practice: Meaning-giving methods in phenomenological research and writing. Walnut Creek, California: Left Coast Press Inc.

Yoshimoto, M. (2011). Curriculum as zen: Five moments inspired by Aoki. Journal of Curriculum Theorizing, 27(3), 76-88. 